\title{
ROUNDTABLE SESSION 3 \\ PHYLOGENY OF EUROPEAN CRAYFISH - IMPROVING THE TAXONOMY OF EUROPEAN CRAYFISH FOR A BETTER CONSERVATION
}

\author{
H.K. SCHULZ (1) and F. GRANDJEAN (2)
}

(1) Institute of Environmental Sciences, University Koblenz-Landau, Fortstrasse 7, D-76829 Landau, Germany.

E-Mail: h.schulz@uni-landau.de

(2) Laboratoire de Génétique et Biologie des Populations de Crustacés, Université de Poitiers, 42 avenue du recteur Pineau, 86022 Poitiers cedex, France.

E-Mail: frederic.grandjean@univ-poitiers.fr

Reçu le 11 mai 2005

Received May 11, 2005

\begin{abstract}
This paper summarizes the various themes discussed in a roundtable session on the uses and usefulness of genetics for conservation of our European crayfish heritage. After reviewing the importance of characterizing the different genetic stocks (ESU: Evolutionary Significant Units) of a species, where morphological criteria used for taxonomy, are utilizable with caution, the present state of knowledge of the phylogeny of European species was determined, in particular for the genus Austropotamobius which occupies most studies. There was a lively debate on the elevation to species rank of $A$. italicus. The status of knowledge of the taxonomy of Astacus astacus has been presented. Finally, given a major increase in works describing the genetic variability of natural populations of European crayfish, it was evident that an up to date inventory of the different research teams in this field should be developed, for several reasons - (i) to describe these teams and their managers (thus facilitating contact) (ii) to list the species studied and the markers used (iii) to give some recommendations on standardizing the use of certain markers or genes so as to allow comparison between the results collected by the various teams, and to apply them on a broader geographic scale.
\end{abstract}

Key-words: conservation genetics, taxonomy, Austropotamobius pallipes, Astacus astacus.

\section{TABLE RONDE 3 \\ PHYLOGÉNIE DES ÉCREVISSES EUROPÉENNES ; AMÉLIORATION DE LA TAXONOMIE DES ÉCREVISSES EUROPÉENNES POUR UNE MEILLEURE CONSERVATION}

\section{RÉSUMÉ}

Cet article résume les différents thèmes abordés lors d'une table ronde portant sur l'utilité et l'utilisation de la génétique pour la conservation du patrimoine astacicole européen. 
Après avoir rappelé l'importance de caractériser les différents stocks génétiques d'une espèce (UES, Unités Evolutives Significatives), en particulier, quand les critères morphologiques, utilisés en taxonomie, sont prendre avec prudence, un état des connaissances sur la phylogénie des espèces européennes a été effectué, et ce, plus particulièrement, chez le genre Austropotamobius qui draine la majeure partie des travaux scientifiques. Le débat sur l'élévation au rang d'espèce d'A. italicus a été très animé. L'état des connaissances sur la taxonomie d'Astacus astacus a été présenté. Étant donné, l'augmentation importante des travaux décrivant la variabilité au sein des populations naturelles des écrevisses européennes, II devenait très important de réaliser un inventaire actualisé des différentes équipes de recherche dans ce domaine pour plusieurs raisons:

(1) Faire connaître ces équipes (faciliter les contacts).

(2) Recenser les espèces étudiées et les marqueurs utilisés.

(3) Proposer des recommandations pour uniformiser l'utilisation de certains marqueurs ou gènes afin de permettre des comparaisons entre les résultats collectés par les différentes équipes de recherche et de les exploiter sur une échelle géographique plus large.

Mots-clés : génétique de la conservation, taxonomie, Austropotamobius pallipes, Astacus astacus.

\section{INTRODUCTION}

As introduced by Professor Steven Weiss of the University of Graz (Austria) at the start of this meeting, there are two distinct considerations concerning genetic diversity of managed species.

First is the recognition of distinct evolutionary lineages, be they species, or some sub-specific entity. This step is very important because it allows a clearer picture of the evolutionary entities at an intraspecific level and to make some inferences in taxonomy when this remains unresolved.

The second level of consideration is genetic diversity at the population level. Population levels are usually assessed using multi-locus approaches. Such assessment is useful in defining a baseline for monitoring loss or preservation of genetic diversity in nature, or within the context of a captive breeding and restocking program.

These two approaches involving the disciplines of phylogeny and phylogeography for the first, and population genetics for the second, were developed using techniques of molecular markers. The principal applications of these molecular markers for the conservation of our crayfish heritage, have concentrated upon the white-clawed crayfish, Austropotamobius pallipes complex, where classical taxonomic methods are often inadequate to differentiate groups along phylogenetic lines and also to provide a precise delimitation of closely related species or intraspecific taxa. Several studies have shown that an inadequate taxonomy could have dramatic consequences for management schemes, as for example reported for the tuatara lizards of New Zealand (DAUGHERTY et al., 1990).

For example, in the white-clawed crayfish complex, Austropotamobius pallipes, examination of large numbers of specimens over relatively broad geographical ranges has revealed a striking degree of intraspecific morphological and meristic variation which has cast doubt on the taxonomic usefulness of several morphological features and left some taxonomic issues still controversial (BOTT, 1950, 1972; KARAMAN, 1963; ALBRECHT, 1983; BRODSKY, 1983; STAROBOGATOV, 1995; GRANDJEAN et al., 1998). 
Before the application of molecular markers, all authors ascribed a specific or subspecific status to Spanish crayfish, as either Austropotamobius lusitanicus or $A$. italicus lusitanicus. However, the molecular data provide a robust phylogeny which does not support this specific or subspecific status (GRANDJEAN et al., 2000, 2001, TRONTELJ et al., 2005). Other important revisions have also been made for the status of Swiss, Austrian, Italian and Slovenian crayfish.

These results indicate the need to revise the taxonomy of other European crayfish genera in the light of molecular data: (i) to describe the biodiversity and (ii) to improve management plans to avoid loss of specific forms, and to restrict translocations between different forms, which are a threat to the genetic integrity of the endemic species or populations.

\section{Phylogeny of Austropotamobius pallipes complex: 1 or 2 species?}

European crayfish have been subjected to a number of taxomomic revisions that have, at the simplest level, produced a system with one genus and five species (HOLDICH, 2002) and at the most complex, five genera and 19 species (STAROBOGATOV, 1995).

Among the European crayfish, the genus Austropotamobius has probably been the most studied due to its wide distribution. It is widespread throughout Europe from the Iberian peninsula in the west to the Balkans Peninsula in the east, and the British Isles in the north (HOLDICH, 2002). It comprises two species characterized by morphological, ecological and genetical criteria, A.torrentium and A. pallipes. However, the situation within each species is more complicated especially for the white-clawed crayfish (Austropotamobius pallipes). As stated in the introduction, its taxonomy is still under debate (summarized in GRANDJEAN et al., 2002) in spite of good advances in the phylogeny and phylogeography of this species (GRANDJEAN et al., 1998, 2002; FRATINI et al., 2005).

The round table started by summarizing recent advances in genetics research showing a clear geographical pattern of genetic diversity which led to the following question.

\section{Why should we give a specific status to Austropotamobius italicus?}

This question was the subject of a lively debate because, apart from its taxonomic implications, it is crucial for the preservation of white-clawed crayfish. In effect, managers who understand the biological will know that two specimens from different species cannot leave viable or fertile lineages. In every restocking operation this is a fundamental criterion that managers must apply and respect. In the past, numerous restocking works led to mingling of these two entities because they were considered as a single species. In the case of the North of Italy where both species are present, the fact of giving a specific status to each will help to limit the risk of mixing them when restocking or rebuilding a population. Further, it can allow a better understanding of diversity within our European crayfish heritage on the part of both managers and the general public, as well as to give impetus to scientific studies on other genera such as Astacus where few data are currently available.

We have selected some sentences from among those pronounced during this roundtable to show the diversity of opinions.

According to Leopold Füreder: we don't define new species in apples, so why would we do it with crayfish? Lets keep pallipes and call the rest subspecies!

Ralf Schultz answered: but manager will know what a species is, but maybe not understand fully what a subspecies is.

Stephen Weiss: we can go on about "what is a species" for ever, it doesn't matter what we call it, don't forget that sometimes there are good species which correspond geographically, that should be preserve. 


\section{What are the scientific arguments to raise Italicus to species level?}

Several papers published in recent decades have provided evidence relevant to defining species boundaries in the Austropotamobius pallipes complex. These data include allozymes, morphological characters and MtDNA data. They indicate that most populations of pallipes and italicus are diagnosably distinct taxa, but previous workers have disagreed on the extent of intergradation. MtDNA data support the recognition of separate species, based on:

(1) the relatively deep differentiation and reciprocal monophyly of pallipes and italicus: the pallipes and italicus groups differ from one another by around $4 \%$ (range based on 16SRNA data $=3.6 \%$ to $5.4 \%$ ). Using a conservative mitochondrial calibration of $2 \%$ sequence divergence/million years (WILSON et al., 1985), this suggests that pallipes and italicus groups have been isolated from one another for approximately 2.5 million years. If we study the results of other studies in which the same gene segment has been used on other crayfish, this 5\% divergence would indicate species-level differences. Separate species status for pallipes and italicus was proposed originally by GRANDJEAN et al. (2002), and accumulating evidence favours that interpretation. All evidence indicates that over most of their respective ranges, pallipes and italicus are biologically quite different crayfish. Average allozyme differentiation is reasonably large between the two taxa, and this has been replicated in two relatively small studies with Nei's Dn $=0.3$ (SANTUCCI et al., 1997) and 0.12 (LÖRTSCHER et al., 1997). These values are at the characteristic intra-/interspecific boundary for species recognition. Moreover, SANTUCCI et al. (1997) revealed a lack of $\mathrm{F} 1$ hybrids in sympatric areas which demonstrates their reproductive isolation in the field;

(2) and Morphological criteria: LAURENT and SUSCILLON (1962) and GRANDJEAN et al. (1998) reported a A/R ratio (apex to rostrum length ratio) of approximately 0.22 for populations sampled in France and England, while populations from Balkans, Italy and Spain had ratios greater than 0.29. Similarly, the number of spines behind the cervical groove also allowed the discrimination of two geographically separated clades (LAURENT and SUSCILLON, 1962; ALBRECHT, 1982; GRANDJEAN et al., 1998). Individuals of pallipes had a significantly higher number of spines (mean 2.8) than those of italicus (mean 1).

At present, however, most authorities consider the Austropotamobius group to be composed of only two species (A. pallipes and $A$. torrentium) with 6 subspecies. Some of them think that to raise $A$. italicus to a full species could be a help to conservation of the white clawed crayfish. In the past, conservation programmes for a given species consisted in restoring the habitat and in translocating individuals without a knowledge of their taxonomic status. Thus, several translocations with animals from different countries, and thus different taxonomic status, have been performed in the same location creating mixed populations. Many examples have been described from across western Europe. For example, Lac Pavin is a lake formed only 6,000 years ago by volcanic explosion where the first introduction of crayfish was reported by Rico in 1876 from 200 animals of unknown origin. Today, this location contains both $A$. pallipes and $A$. italicus, which implies at least one secondary human introduction. In south of France, a brook called Garrel contains both $A$. pallipes and $A$. italicus but $A$. pallipes was met with in stronger density. The presence of A. italicus probably results from translocations used to augment this small population of native individuals following a strong decrease of population size at some time in the past. SANTUCCl et al. (1997) reported other examples of mixed populations in Italy.

If increasing the population size in declining populations is an important rule in conservation genetics to avoid inbreeding depression (the decrease in growth, survival or fertility often observed after matings between relatives), we absolutely need to take into account the status of the specimens used for all reinforcement operations. 


\section{Table I}

Current research activities in phylogenetics and population genetics of European crayfish species.

Tableau I

Liste de référence des équipes de recherche travaillant sur les écrevisses européennes dans le domaine de la génétique des populations et de la phylogénie.

\begin{tabular}{|c|c|c|c|c|}
\hline Working Group & Species & Applied Markers & Scale & Objectives \\
\hline $\begin{array}{l}\text { University Braunschweig/ } \\
\text { University of Koblenz- } \\
\text { Landau, Germany }\end{array}$ & A. astacus & RAPD, ISSR-PCR & Central Europe & $\begin{array}{l}\text { Population } \\
\text { differentiation }\end{array}$ \\
\hline $\begin{array}{l}\text { University Poitiers, } \\
\text { France }\end{array}$ & $\begin{array}{l}\text { A. pallipes, } \\
\text { A. Italicus, } \\
\text { A. torrentium }\end{array}$ & $\begin{array}{l}\text { RAPD, } \\
\text { Microsatellite, } \\
16 \text { S RNA, COI } \\
\text { (mtDNA) }\end{array}$ & Western Europe & \begin{tabular}{|l|} 
Population \\
differentiation, \\
Phylogeography, \\
Phylogeny \\
\end{tabular} \\
\hline $\begin{array}{l}\text { University Ljubljana, } \\
\text { Slovenia }\end{array}$ & $\begin{array}{l}\text { A. pallipes, } \\
\text { A. Italicus, } \\
\text { A. torrentium }\end{array}$ & $\mathrm{COI}$ & \begin{tabular}{|l|} 
Western \\
Europe, \\
Balkans
\end{tabular} & $\begin{array}{l}\text { Phylogeography, } \\
\text { Phylogeny }\end{array}$ \\
\hline $\begin{array}{l}\text { University Innsbruck, } \\
\text { Austria }\end{array}$ & A. italicus & $\begin{array}{l}\text { Microsatellite, } \\
\text { Sequence analysis } \\
\text { (16 S RNA, COI) } \\
\end{array}$ & $\begin{array}{l}\text { South Tyrol } \\
\text { (Northern Italy) }\end{array}$ & $\begin{array}{l}\text { Population } \\
\text { differentiation }\end{array}$ \\
\hline $\begin{array}{l}\text { Research Centre for } \\
\text { Agriculture and Forestry } \\
\text { Laimburg, Italy }\end{array}$ & A. italicus & $\begin{array}{l}\text { Microsatellite, } \\
\text { Sequence analysis } \\
\text { (16 S RNA, COI) }\end{array}$ & $\begin{array}{l}\text { South Tyrol } \\
\text { (Northern Italy) }\end{array}$ & $\begin{array}{l}\text { Population } \\
\text { differentiation }\end{array}$ \\
\hline University Sannio, Italy & A. italicus & Microsatellite & $\begin{array}{l}\text { Fruili Venezia } \\
\text { Guilia Region } \\
\text { (Italy) }\end{array}$ & \begin{tabular}{|l} 
Population \\
differentiation
\end{tabular} \\
\hline $\begin{array}{l}\text { University Regensburg, } \\
\text { Germany }\end{array}$ & A. torrentium & $\begin{array}{l}\text { Sequence analysis } \\
\text { (16 S RNA, COI) }\end{array}$ & \begin{tabular}{|l|} 
Southern \\
Germany \\
\end{tabular} & $\begin{array}{l}\text { Population } \\
\text { differentiation }\end{array}$ \\
\hline University Firenze, Italy & A. italicus & $\begin{array}{l}\text { Microsatellite. } \\
\text { Sequence analysis } \\
\text { (16 S RNA, COI) }\end{array}$ & \begin{tabular}{|l|} 
Toscany Region \\
(italy)
\end{tabular} & \begin{tabular}{|l|} 
Population \\
differentiation, \\
Phylogeography, \\
Phylogeny \\
\end{tabular} \\
\hline University Udine, Italy & A. italicus & $\begin{array}{l}\text { Microsatellite, } \\
\text { Sequence analysis } \\
\text { (16 S RNA, COI) }\end{array}$ & $\begin{array}{l}\text { Toscany Region } \\
\text { (italy) }\end{array}$ & \begin{tabular}{|l|} 
Population \\
differentiation, \\
Phylogeography, \\
Phylogeny \\
\end{tabular} \\
\hline University Madrid, Spain & A. italicus & RAPD & Spain & \begin{tabular}{|l|} 
Population \\
differentiation
\end{tabular} \\
\hline $\begin{array}{l}\text { National Board of } \\
\text { fisheries Drottningholm, } \\
\text { Sweden }\end{array}$ & A. astacus & Microsatellite & Sweden & $\begin{array}{l}\text { Population } \\
\text { differentiation }\end{array}$ \\
\hline University Cardiff, Wales & A. pallipes & Microsatellite & Wales & $\begin{array}{l}\text { Population } \\
\text { differentiation }\end{array}$ \\
\hline $\begin{array}{l}\text { University of Insubria, } \\
\text { Italy }\end{array}$ & A. italicus & Sequence analysis & Italy & $\begin{array}{l}\text { Population } \\
\text { differentiation }\end{array}$ \\
\hline $\begin{array}{l}\text { University of Eastern } \\
\text { Piedmont, Italy }\end{array}$ & $\begin{array}{l}\text { A. pallipes, } \\
\text { A. italicus }\end{array}$ & & Italy & $\begin{array}{l}\text { Population } \\
\text { differentiation }\end{array}$ \\
\hline $\begin{array}{l}\text { University of Kuopio, } \\
\text { Finland }\end{array}$ & A. astacus & & Finland & $\begin{array}{l}\text { Population } \\
\text { differentiation }\end{array}$ \\
\hline
\end{tabular}




\section{Phylogeny of Astacus astacus: status of knowledge}

Based on morphological studies ALBRECHT (1982) and KARAMAN (1963) recognized three subspecies of $A$. astacus, i.e. A. a. astacus, A. a. balcanicus and A. a. colchicus. The recent distribution range of the subspecies $A$. a. astacus extends from the Balkan, over mid- and western Europe up to Scandinavia and large parts of eastern Europe to the White Sea in the north. A. a. balcanicus is endemic in the western Balkans, concentrated in the Vardar drainage system in Macedonia and Greece and the Lake Ohrid in Greece. A. a. colchicus occurs in an isolated area of the upper Rion in the Caucasus. ALBRECHT (1983) presumed that the northern borderline of crayfish during last ice age coincided with the southern borderline of the permafrost. Based on the absence of $A$. astacus on the British Isle it can be concluded that the noble crayfish did not belong to the glacial mixed fauna of the ice-free belt between the northern ice cap and the Alps (THIENEMANN, 1950). A. a. astacus was presumably restricted to the Balkans and northern Greece. Following the deglaciation $A$. astacus migrated into Europe using the Danube drainage system. ALBRECHT (1983) stated that the occurrence of the noble crayfish in Scandinavia originates from introductions in the 16th century and also questioned the natural post-Pleistocene colonization of northern Germany and eastern Europe. Human introductions of noble crayfish could have served as strong bottlenecks resulting in populations with reduced genetic diversity.

In contrast, SKURDAL et al. (1999) reported that fossil remains of crayfish were found in southern Finland in deposits originating from the Littorina period (c. 3,000$1,000 \mathrm{BC}$ ). A number of possible paths for the recolonization of northern European rivers by some fish species following the glacial retreat have already been discussed by several authors (e.g. DURAND et al. (1999) and GARCIA-MARIN et al. (1999)). Concluding from the recent widespread distribution of the noble crayfish which extends northwards to the Polar Circle (northernmost population in Lake Leppäjärvi, Finland at $67^{\circ} 30^{\prime} \mathrm{N}$ ) (WESTMAN, 1991), an early migration northwards is conceivable. At this time many ice-damned lakes and ice-marginal streamways discharged southwards into the Aral, Caspian and Black Seas (GIBBARD, 1988; GROSSWALD, 1980).

Based on morphological criteria KARAMAN (1963) recognized three races in the subspecies $A$. a. astacus. The northern race $A$. a. astacus natio astacus inhabitats the Elbe, the Oder and presumably other river systems draining to the North Sea and the Baltic Sea. The southern race $A$. a. astacus natio canadziae was found in the tributaries of the Danube in the area of Croatia and presumably in Serbia and Romania. A third race is described for the upper Danube including the River Drava. Up to date genetic studies of the noble crayfish included only a small number of populations or focussed on specific parts of the distribution area and were not appropriate to reconstruct phylogenetic relationships on a European wide level (AGERBERG, 1990; EDSMAN et al., 2002; FEVOLDEN and HESSEN, 1989; FEVOLDEN et al., 1994; SCHULZ, 2000; SCHULZ et al., 2004). The application of the isozyme electrophoresis revealed no (AGERBERG, 1990) or only low levels of allele frequency differences between populations in Norway and Sweden (FEVOLDEN and HESSEN, 1989; FEVOLDEN et al., 1994). The molecular markers RAPDPCR (SCHULZ, 2000), microsatellite length variation in the ITS1 region (EDSMAN et al., 2002) and ISSR-PCR (SCHULZ et al., 2004), by contrast, showed significant differences between populations over short geographic distances. These differences were most likely due to founder effects and genetic drift. Furthermore, EDSMAN et al. (2002) detected strong genetic differences between noble crayfish populations from Sweden and from two locations in Montenegro (drainages of the Danube) which revealed unique genotypes not found in the Swedish crayfish material and may reflect differences between two different races as described by KARAMAN (1963).

Future steps for the reconstruction of phylogenetic relationships in $A$. astacus should include the analysis of MtDNA on a European scale similar to studies in A. pallipes. 
The inclusion of populations covering the whole distribution area of $A$. astacus, especially from regions which are presumed as Ice age refugia in $A$. astacus and other freshwater species, are necessary prerequisites. (Table 1).

Finally, a list of European team working on genetics in crayfish is presented

\section{REFERENCES}

AGERBERG A., 1990. Genetic variation in three species of freshwater crayfish; Astacus astacus L., Astacus leptodactylus Aesch., and Pacifastacus leniusculus (Dana), revealed by isozyme electrophoresis. Hereditas, 113, 101-108.

ALBRECHT H., 1982. Das system der europäischen flusskrebse (Decapoda, Astacidae): vorschlag und begrundung. Mitteilungen aus dem Hamburgischen Zoologischen Museum Institut, 79, 187-210.

ALBRECHT H., 1983. Besiedlungsgeschichte und ursprünglich holozane verbreitung der europäischen Flusskrebse. Spixiana, 6, 61-77.

BOTT R., 1950. Die Flusskrebse europas (Decapoda, Astacidae). Proceedings of the Senckenberg Naturalist Society, 483, 1-36.

BOTT R., 1972. Besiedlungsgeschichte and systematic des Astacieden West-Europas unter besonderer beruchksichtigung der schweiz. Revue Suisse de Zoologie, 79, 387-408.

BRODSKY S.Y., 1983. On the systematics of palaeartic crayfishes (Crustacea, Astacidae). Freshwater crayfish, 5, 464-470.

DAUGHERTY C.H., CREE A., HAY J.M., THOMPSON M.B., 1990. Neglected taxonomy and continuing extinctions of tuatara (sphenodon) Nature, 347 (6289), 177-179.

DURAND J.D., PERSAT H., BOUVET Y., 1999. Phylogeography and postglacial dispersion of the chub (Leuciscus cephalus) in Europe. Molecular Ecology, 8, 989-997.

EDSMAN L., FARRIS J.S., KALLERSJO M., PRESTEGAARD T., 2002. Genetic differentiation between noble crayfish, Astacus astacus (L.), populations detected by microsatellite length variation in the rDNA ITS1 region. Bull. Fr. Pêche Piscic., 367, 691-706.

FRATINI S., ZACCARA S., BARBARESI S., GRANDJEAN F., SOUTY-GROSSET C., CROSA G., GHERARDI F., 2005. Phylogeography of the threatened crayfish (genus Austropotamobius) in Italy: Implication for its conservation. Heredity, 94,108-118.

FEVOLDEN S.E., HESSEN D.O., 1989. Morphological and genetic differences among recently founded populationsof noble crayfish (Astacus astacus). Hereditas, 110, 149-158.

FEVOLDEN S.E., TAUGBOL T., SKURDAL J., 1994. Allozymic variation among populations of noble crayfish, Astacus astacus L., in southern Norway: implications for management. Aquaculture and Management, 25, 927-935.

GARCIA-MARIN J.L., UTTER F.M., PLA C., 1999. Postglacial colonization of brown trout in Europe based on distribution of allozyme variants. Heredity, 82, 46-56.

GIBBARD P.L., 1988. The history of the great northwest European rivers during the past three million years. Philosophical Transactions of the Royal Society of London. Series B. Biological sciences, 318, 554-602.

GRANDJEAN F., GOUIN N., FRELON M., SOUTY-GROSSET C., 1998. Genetic and morphological systematic studies on the crayfish Austropotamobius pallipes (Decapoda: Astacidae). Journal of Crustacean Biology, 18(3), 549-555. 
GRANDJEAN F., HARRIS D.J., SOUTY-GROSSET C., CRANDALL K.A., 2000a. Systematics of the European endangered crayfish species, Austropotamobius pallipes (Decapoda: Astacidae). Journal of Crustacean Biology, 20(3), 522-529.

GRANDJEAN F., GOUIN N., SOUTY-GROSSET C., DIÉGUEZ-URIBEONDO J., 2001. Drastic bottlenecks in the endangered crayfish species Austropotamobius pallipes in Spain and implications for its colonization history. Heredity, 86, 431-438.

GRANDJEAN F., FRELON-RAIMOND M., SOUTY-GROSSET C., 2002. Compilation of molecular data for the phylogeny of the genus Austropotamobius: one or several species?. Bull. Fr. Pêche Piscic., 367, 671-680.

GROSSWALD M.G., 1980. Late Weichselian ice sheet of northern Eurasia. Quaternary Research, 13, 1-32.

HOLDICH D.M., 2002. Distribution of crayfish in Europe and some adjoining countries. Bulletin Français de la Pêche et de la Pisciculture, 367, 611-650.

KARAMAN M. S., 1963. Studie der Astacidae (Crustacea, decapoda). Hydrobiologia, 22, 111-132.

LAURENT P.J., SUSCILLON M., 1962. Les écrevissses en France. Annales de la Station Centrale d'Hydrobiologie, 9, 336-395.

LÖRTSCHER M., STUCKI T.P., CLALUNA M., SCHOLL A., 1997. Phylogeographic structure of Austropotamobius pallipes populations in Switzerland. Bull. Fr. Pêche Piscic., 347, 649-661.

SANTUCCI F., IACONNELLI M., ANDREANI P., CIANCHI R., NASCETTI G., BULLINI L., 1997. Allozyme diversity of European freshwater crayfish of the genus Austropotamobius. Bull. Fr. Pêche Piscic., 347, 663-676.

SCHULZ H.K., SMIETANA P., SCHULZ R., 2004. Assessment of DNA variations of the noble crayfish (Astacus astacus L.) in Germany and Poland using Inter-Simple Sequence Repeats (ISSRs). Bull. Fr. Pêche Piscic., 372-373, 387-399.

SCHULZ R., 2000. Status of the noble crayfish Astacus astacus (L.) in Germany: monitoring protocol and the use of RAPD markers to assess the genetic structure of populations. Bull. Fr. Pêche Piscic., 356, 123-138.

SKURDAL J., TAUGBOL T., BURBA A., EDSMAN L., SÖDERBÄCK B., STYRISHAVE B., TUUSTI J., WESTMAN K., 1999. Crayfish introductions in the Nordic and Baltic countries. In: GHERARDI F., HOLDICH D.M. (Eds.), Crayfish in Europe as alien species: how to make the best of a bad situation?, 193-219, A.A. Balkema, Rotterdam.

STAROBOGATOV Y.I., 1995. Taxonomy and geographical distribution of crayfishes of Asia and East Europe (Crustacea: Decapoda: Astacidae). Arthropoda Selecta, 4, 3-25.

THIENEMANN A., 1950. Verbreitungsgeschichte der Süßwassertierwelt Europas: Versuch einer historischen Tiergeographie der europäischen Binnengewässer. E. Schweizerbart'sche Verlagsbuchhandlung, Stuttgart.

TRONTELJ P., MACHINO Y., SKET B., 2005. Phylogenetic and phylogeographic relationships in the crayfish genus Austropotamobius inferred from mitochondrial COI gene sequences. Molecular Phylogenetics and Evolution, 34, 212-226.

WESTMAN K., 1991. The crayfish fishery in Finland: its past, present and future. Finnish Fisheries Research, 12, 187-216.

WILSON A.C., CANN R.L., CARR S.M., 1985. Mitochondrial DNA and two perspectives on evolutionary genetics. Biol. J. Linn. Soc., 26, 375-400. 